\title{
Peningkatan Pengetahuan Masyarakat Melalui Edukasi Tentang Penggunaan Antibiotik Bijak dan Rasional
}

\section{The Improving Knowledge of Community Through Education About the Use of Antibiotics Wisely and Rationally}

\author{
Hanif Nasiatul Baroroh ${ }^{1}$, Esti Dyah Utami², Laksmi Maharani ${ }^{3}$, Ika Mustikaningtias ${ }^{4}$ \\ 1,2,3,4 Jurusan Farmasi, Fakultas Ilmu-Ilmu Kesehatan, \\ Universitas Jenderal Soedirman, Purwokerto \\ ${ }^{1}$ corresponding author : h_baroroh@yahoo.co.id
}

\begin{abstract}
ABSTRAK
Penggunaan antibiotik yang tidak tepat terjadi karena minimalnya informasi dari tenaga kesehatan. Permasalahan tersebut dapat mendorong terjadinya resistensi bakteri terhadap antibiotik pada manusia. Kesadaran dan pengetahuan masyarakat di Desa Sambeng Wetan mengenai penggunaan antibiotik yang rasional masih kurang. Pemberdayaan masyarakat terutama terhadap kader kesehatan perlu dilakukan untuk meningkatkan pengetahuan tentang penggunaan antibiotik. Metode edukasi yang dilaksanakan yaitu dengan metode modul, ceramah dan diskusi. Instrumen penelitian berupa kuesioner yang dibagikan kepada responden sebelum dan sesudah edukasi untuk mengevaluasi tingkat pengetahuan peserta. Kuesioner berisi pertanyaan tertutup terkait pengetahuan penggunaan antibiotik. Data dianalisis dengan uji t berpasangan. Berdasarkan karakteristik peserta, sebagian besar peserta adalah usia dewasa awal (83,87\%). Pendidikan responden sebagian besar adalah tamat SMA (38,71\%) dan berprofesi sebagai ibu rumah tangga (90,32\%). Hasil menunjukkan bahwa rata-rata nilai pengetahuan kader meningkat 0,97 poin setelah dilakukan edukasi. Persentase peningkatan nilai pengetahuan kader sebesar 13,8\% dari rata-rata nilai pengetahuan awal. Edukasi berpengaruh signifikan terhadap tingkat pengetahuan. Kegiatan edukasi dengan metode modul, ceramah dan diskusi mampu meningkatkan pengetahuan dari kader kesehatan. Oleh karena itu perlu dilakukan pemberdayaan masyarakat terutama kader kesehatan secara berkelanjutan sebagai salah satu langkah kongkrit untuk meningkatkan kualitas hidup masyarakat dan mengendalikan resistensi bakteri terhadap antibiotik.
\end{abstract}

Kata kunci : Edukasi, Pengetahuan, Kader kesehatan, Antibiotik

\begin{abstract}
Inappropriate use of antibiotics occurs due to minimal information from health personnel. These problems can encourage bacterial resistance to antibiotics in humans. Awareness and knowledge of the community in Sambeng Wetan Village about the use of rational antibiotics is still lacking. Empowering the community especially health cadres is necessary to increase the knowledge about the use of antibiotics. Module methods, lectures and discussions were used in this eduaction. The research instruments were questionnaires that distributed to respondents before and after education to evaluate the level of participants' knowledge. The questionnaire contains closed questions related to the knowledge of antibiotic use. Data were analyzed by paired t-test. Based on the characteristics of participants, most participants were early adulthood (83.87\%). Most of respondent's education is high school $(38,71 \%)$ and work as housewife (90,32\%). The results showed that the average value of the knowledge was increased by 0.97 points after the education. The percentage of increasing in the knowledge value is $13.8 \%$ from initial knowledge value. After education there was a significant increase in knowledge level. This showed that education with module method, lecture and discussion able to increase knowledge of community. Therefore it is necessary to empower the community, especially health cadres in a sustainable way to raise the quality of life of the community and control bacterial resistance to antibiotics.
\end{abstract}

Keyword : Education, Knowledge, Community, Antibiotic 


\section{PENDAHULUAN}

Resistensi bakteri terhadap antibiotik menimbulkan berbagai permasalahan dan merupakan ancaman global bagi kesehatan. Hal ini terjadi karena penggunaan antibiotik relatif tinggi yang berdampak pada morbiditas, mortalitas, serta dampak ekonomi dan sosial yang tinggi. Saat ini resistensi bakteri telah berkembang di lingkungan masyarakat, khususnya Streptococcus pneumoniae (SP), Staphylococcus aureus, dan Escherichia coli (Mardiastuti, Kurniawati, Kiranasari, Ikaningsih, \& Kadarsih, 2007). Dengan kejadian resistensi antibiotik, potensi antibiotik akan berkurang dalam mengobati infeksi dan penyakit pada manusia, hewan dan tumbuhan. Resistensi antibiotik juga meningkatkan biaya perawatan, akibat penggunaan antibiotik yang lebih mahal dan lebih toksik (Healthcare, 2001). Salah satu solusi untuk mengatasi permasalahan tersebut adalah penggunaan antibiotik yang bijak dan rasional sehingga dapat mengurangi morbiditas dan mortalitas, khususnya penyakit infeksi.

Berdasarkan Laporan terakhir dari (WHO, 2014) dalam Antimicrobial Resistance: Global Report on Surveillance menunjukkan bahwa Asia Tenggara memiliki angka tertinggi dalam kasus resistensi antibotik di dunia, khususnya infeksi yang disebabkan oleh Staphylococcus aureus yang resisten terhadap Methicillin, sehingga mengakibatkan menurunnya fungsi antibiotik tersebut. Resistensi antibiotik telah menjadi masalah lobal yang harus segera diselesaikan. Salah satu solusi yang bisa dilakukan adalah kerjasama antar tenaga kesehatan bersama masyarakat berperan serta dalam Program Pengendalian Resistensi Antimikroba di masyarakat.

Desa Sambeng Wetan merupakan salah satu desa yang terletak di kecamatan Kembaran Kabupaten Banyumas. Jumlah petugas kesehatan di desa tersebut tidak sebanding dengan jumlah penduduk yang sangat membutuhkan perhatian terutama bidang kesehatan khususnya informasi terkait penggunaan obat yang rasional. Penggunaan antibiotik yang tidak tepat terjadi karena minimalnya informasi dari tenaga kesehatan. Penjualan antibiotik secara bebas masih terjadi di apotek, bahkan di warung pun ada penjualan antibiotik. Permasalahan tersebut dapat mendorong terjadinya resistensi bakteri terhadap antibiotik pada manusia. Kesadaran dan pengetahuan masyarakat di Desa Sambeng Wetan mengenai penggunaan antibiotik yang rasional masih kurang. Oleh karena itu perlu dilakukan pemberdayaan masyarakat terutama kader kesehatan sebagai salah satu langkah konkret untuk meningkatkan kualitas hidup masyarakat dan mengendalikan resistensi bakteri terhadap antibiotik.

\section{METODE}

Pemberdayaan masyarakat dilakukan di desa Sambeng Wetan, Kecamatan Kembaran Kabupaten Banyumas. Data pengetahuan diperoleh dengan metode penelitian deskripsi komparatif dengan pendekatan cross- 
sectional, menggunakan instrumen berupa kuesioner. Populasi pada penelitian ini adalah kader kesehatan di Desa Sambeng Wetan yang berjumlah 60 orang. Penelitian ini dilakukan dengan pelaksanaan pretest, edukasi, dan posttest. Jumlah sampel dalam penelitian ini adalah 31 orang yang ditentukan dengan teknik purposive sampling, yaitu dari kader kesehatan yang mengikuti edukasi. Kriteria inklusi adalah kader kesehatan yang aktif di posyandu, hadir pada saat kegiatan edukasi dan bersedia mengikuti penelitian. Kegiatan edukasi dengan metode modul, ceramah dan diskusi. Modul berisi tentang pengetahuan pengenalan dan tujuan penggunaan antibiotik, penggunaan antibiotik bijak dan rasional dan resistensi antibiotik. Pemberian modul dan penjelasan oleh pelatih (Tim pengabdian) tentang proses belajar menggunakan modul, pemberian materi, diskusi masalah dalam kelompok ( \pm 5 orang per kelompok) dengan arahan dari pelatih, pelaksanaan simulasi atau praktek pemberian informasi terkait penggunaan antibiotik kepada masyarakat, serta pembahasan bersama dengan pelatih. Ceramah disampaikan oleh Tim Pengabdian dengan materi yaitu Penggunaan Antibiotik Bijak dan Rasional.

Kuesioner dibagikan kepada responden sebelum dan sesudah memperoleh edukasi. Kuesioner berisi 10 pertanyaan tertutup terkait pengetahuan mengenai penggunaan antibiotik. Data skor pre-test dan post-test yang diperoleh dalam penelitian ini kemudian diolah dan dianalisis menggunakan uji $\mathrm{t}$ berpasangan.
Data skor pre-test dan post-test dihitung persentase jumlah dan dimasukkan ke dalam kriteria objektif meliputi : 76-100\% kategori baik, 56-75\% kategori cukup, 40-55\% kategori kurang dan $<40 \%$ kategori buruk.

\section{HASIL DAN PEMBAHASAN}

Kegiatan edukasi dilaksanakan dengan tujuan untuk meningkatkan pengetahuan dan keterampilan masyarakat terutama kader kesehatan sebagai salah satu langkah awal dalam mendukung program pengendalian antimikroba di masyarakat. Berdasarkan Sistem Kesehatan Nasional, kesehatan tidak hanya menjadi tanggung jawab tenaga kesehatan saja akan tetapi membutuhkan peran serta masyarakat. Untuk mewujudkan derajat kesehatan masyarakat diselenggarakan upaya kesehatan yang terpadu dan menyeluruh dalam bentuk upaya kesehatan perseorangan dan upaya kesehatan masyarakat. Permasalahan tentang kesehatan di desa Sambeng Wetan Kembaran Kabupaten Banyumas salah satunya adalah terkait dengan kesadaran dan pengetahuan masyarakat mengenai penggunaan antibiotik yang rasional masih kurang. Masyarakat masih membutuhkan upaya lebih keras dari semua pihak terutama tenaga kesehatan untuk dapat memahami penggunaan antibiotik yang bijak dan rasional sehingga bisa mendukung program pemerintah tentang pengendalian resistensi antimikroba.

Kuesioner pengetahuan tentang penggunaan antibiotik rasional diberikan 
kepada kader kesehatan di Desa Sambeng Wetan, Kab.Banyumas yang berjumlah \pm 60 orang. Namun pada saat pelaksanaan hanya 35 orang yang bersedia mengikuti kegiatan edukasi dan mengisi kuesioner tersebut. Dari 35 kuesioner yang terisi, terdapat 1 kuesioner yang tidak diisi post-test nya, dan 3 kuesioner yang tidak diisi data diri responden, sehingga tidak dianalisis. Total kuesioner yang dianalisis adalah 31 kuesioner pre-test dan post-test.

Responden dikategorikan berdasarkan usia, pendidikan, status perkawinan, dan pekerjaan. Pembagian usia mengacu pada pembagian menurut (WHO, World Report On Ageing And Health, 2015) yaitu dewasa (17-45 ta hun) dan lansia awal (middle age) yaitu 46-55 tahun. Persentase karakteristik responden disajikan dalam tabel 1.

Data menunjukkan bahwa sebagian besar responden merupakan usia dewasa awal $(83,87 \%)$. Pendidikan responden sebagian besar adalah tamat SMA $(38,71 \%)$ dan berprofesi sebagai ibu rumah tangga (90,32\%). Semua responden sudah menikah. Hasil ini sejalan dengan penelitian tentang kader posyandu yang dilaksanakan (Maretha $\mathrm{H}$., 2012) bahwa sebagian besar kader merupakan usia dewasa di bawah 50 tahun, bekerja sebagai ibu rumah tangga dan memiliki latar belakang pendidikan tamat SMA. Umur, pendidikan, dan pekerjaan tidak berhubungan secara statistik terhadap pengetahuan kader posyandu (Maretha H., 2012), meskipun salah satu syarat menjadi kader adalah bisa membaca dan menulis, sehingga pendidikan dipertimbangkan dalam pemilihan kader. Menurut (Potter \& Perry , 2005) pendidikan dapat mempengaruhi pikiran seseorang sehingga tingkat pendidikan dapat meningkatkan pengetahuan tentang kesehatan. .

Pengetahuan Kader PKK terhadap penggunaan antibiotik yang rasional diukur menggunakan kuesioner 10 item pertanyaan. Kuesioner diberikan sebelum kader

Tabel 1. Karakteristik Responden

\begin{tabular}{lcc}
\hline \multicolumn{1}{c}{ Karakteristik } & Jumlah Responden (orang) & Persentase \\
\hline Usia & 26 & \\
Dewasa (17-45 tahun) & 5 & $83,87 \%$ \\
Lansia Awal (46-55) tahun) & \multicolumn{1}{c}{} \\
\hline Pendidikan & 9 & $29,13 \%$ \\
$\quad$ Tamat SD & 9 & $29,03 \%$ \\
Tamat SMP & 12 & $38,71 \%$ \\
Tamat SMA & 1 & $3,23 \%$ \\
$\quad$ Tamat Diploma/ Sarjana & & \\
\hline Status Perkawinan & 31 & $100 \%$ \\
$\quad$ Menikah & & \\
\hline Pekerjaan & 28 & $90,32 \%$ \\
Ibu Rumah Tangga & 1 & $3,23 \%$ \\
PNS & 1 & $3,23 \%$ \\
Buruh & 1 & $3,23 \%$ \\
$\quad$ Perangkat Desa & &
\end{tabular}


mendapatkan modul dan penyuluhan mengenai penggunaan antibiotik rasional (pretest) dan setelah selesai penyuluhan (post-test). Hasil pengetahuan kader tertulis dalam Tabel 2 dan 3.

Berdasarkan hasil penelitian menunjukkan bahwa sebelum pemberian edukasi, responden yang memiliki pengetahuan yang baik berjumlah 12 orang $(38,71 \%)$, pengetahuan cukup berjumlah $14(45,16 \%)$ dan masih terdapat 5 orang $(16,13 \%)$ yang memiliki tingkat pengetahuan yang kurang mengenai penggunaan antibiotik yang bijak dan rasional (Tabel 2). Hal ini terjadi karena kader kesehatan belum banyak yang mengikuti kegiatan penyuluhan tentang informasi obat. Edukasi modul dan ceramah berupa pengenalan dan tujuan penggunaan antibiotik, penggunaan antibiotik bijak dan rasional dan resistensi antibiotik. Setelah dilakukan edukasi tingkat pengetahuan responden dengan kategori baik berjumlah 19 orang $(61,29 \%)$ dan kategori cukup berjumlah 12 orang $(38,71 \%)$. Setelah dilakukan edukasi tingkat pengetahuan kader kesehatan meningkat menjadi kategori baik dan cukup. Sehingga harapannya kader kesehatan akan melakukan edukasi kepada masyarakat sehingga kepatuhan masyarakat dalam penggunaan antibiotik akan meningkat.

Informasi penggunaan antibiotik kepada masyarakat sangatlah penting. Antibiotik adalah zat-zat kimia yang diproduksi oleh fungi dan bakteri yang memiliki efek menghambat pertumbuhan atau membunuh kuman, sedangkan toksisitasnya bagi manusia relatif kecil (Neal , 2006). Antibiotik biasanya digunakan untuk terapi empiris, definitif, dan pencegahan (profilaksis). Terapi empiris merupakan terapi awal yang digunakan sebelum data laboratorium ada. Pemberian antibiotik sebaiknya dilakukan dengan pertimbangan educated guess (dugaan berbasis pengetahuan) dari penelitian terkini berdasarkan gambaran penyakit tertentu yang mengarah pada kuman tertentu sesuai dengan kuman terbanyak di daerah tersebut (Leekha, Terrel, \& Edson, 2011).

Pada beberapa penelitian mengenai penggunaan antibiotik untuk pasien rawat jalan, diketahui hanya $69 \%$ dari pasien di seluruh dunia yang menyelesaikan pengobatan antibiotik hingga tuntas atau hingga obat yang diberikan seluruhnya habis (Pechere, 2001). Rendahnya pengetahuan tentang penggunaan antibiotik dan kepatuhan terhadap pengobatan

Tabel 2. Tingkat Pengetahuan responden berdasarkan total nilai pre-test dan post-test

\begin{tabular}{ccccc}
\hline \multirow{2}{*}{ Kategori Penilaian } & \multicolumn{2}{c}{ Pre-tes } & \multicolumn{2}{c}{ Post-tes } \\
\cline { 2 - 5 } & Frekuensi & $\%$ & Frekuensi & $\%$ \\
\hline Baik & 12 & 38,71 & 19 & 61,29 \\
Cukup & 14 & 45,16 & 12 & 38,71 \\
Kurang & 5 & 16,13 & 0 & 0 \\
Buruk & 0 & 0 & 0 & 0 \\
\hline
\end{tabular}

Keterangan: $\%=$ persentase 
seperti inilah yang menyebabkan terjadinya resiko resistensi bakteri terhadap antibiotik.

Resistensi antibiotik terjadi karena penggunaannya yang meluas dan tidak rasional. Pasien di rumah sakit lebih dari separuh mendapatkan terapi antibiotik sebagai pengobatan ataupun profilaksis. Sebagian besar penggunaan antibiotik dipakai untuk kepentingan manusia (80\%) dan penggunaan antibiotik digunakan dengan indikasi yang kurang tepat (sedikitnya 40\%), misalnya infeksi virus (KEMENKES RI, 2011). Disinilah peran kader kesehatan untuk membantu menurunkan kejadian resistensi antibiotik.

Berdasarkan hasil uji beda pada tingkat pengetahuan sebelum dan sesudah edukasi menunjukkan bahwa rata-rata nilai pengetahuan kader kesehatan meningkat 0,94 poin setelah dilakukan edukasi (Tabel 3). Persentase peningkatan nilai pengetahuan kader sebesar $13,8 \%$ dari rata-rata nilai pengetahuan awal. Data hasil pre-test dan s elanjutnya dianalisis secara statistik. Hasil pretest dan post-test diuji normalitas menggunakan uji saphiro-wilk, dan menunjukkan baik data pre-test maupun posttest terdistribusi normal $(\mathrm{p}=0,091 ; 0,063)$. Karena data terdistribusi normal, maka dilakukan uji beda menggunakan uji t berpasangan. Hasil menunjukkan bahwa nilai pre-test dan post-test berbeda signifikan $(\mathrm{p}=0,002)$ sehingga dapat disimpulkan bahwa pemberian penyuluhan dan modul pada kader kesehatan mampu meningkatkan pengetahuan kader secara signifikan dengan peningkatan nilai sebesar $13,37 \%$ dari nilai pengetahuan awal.

Terjadinya peningkatan pengetahuan disebabkan karena adanya edukasi diberikan modul dan penyuluhan. Modul dapat memperjelas informasi atau pesan pengajaran (Slameto, 2005). Menurut (Notoatmodjo, 2005) edukasi merupakan pengalaman belajar untuk mempengaruhi sikap, dan perilaku. (Jumiyati, Nugrahaeni, \& Margawati, 2014) melaporkan bahwa pelatihan dengan menggunakan modul dapat meningkatkan pengetahuan, sikap dan praktik kader kesehatan dibandingkan kelompok kontrol. (Pratiwi, Nuryanti, Utami, Warsinah, \& Sholihat, 2016) juga melaporkan bahwa dengan edukasi berkelompok juga mampu meningkatkan pengetahuan masyarakat tentang informasi obat.

Penyuluhan kesehatan merupakan suatu bentuk kegiatan edukasi yang dapat mempengaruhi pengetahuan dan sikap. Dengan adanya kegiatan edukasi berupa penyuluhan maka responden akan memperoleh pembelajaran dan informasi yang

Tabel 3. Pengaruh edukasi terhadap pengetahuan responden terhadap penggunaan antibiotik yang rasional

\begin{tabular}{ccccc}
\hline Jenis Kuesioner & Nilai Terendah & Nilai Tertinggi & Rata-rata \pm SD & p-value \\
\hline Pre-test & 4 & 10 & $7,03 \pm 1,354$ & 0,002 \\
Post-Test & 6 & 10 & $7,97 \pm 1,303$ & \\
\hline
\end{tabular}


menghasilkan suatu perubahan perilaku termasuk pengetahuan dan sikap.

Oleh karena itu, kegiatan edukasi ini perlu terus dikembangkan secara berkesinambungan sebagai salah satu pendukung keberhasilan upaya pengendalian resistensi antibiotik. Dengan meningkatnya tingkat pengetahuan kader kesehatan, maka diharapkan akan dapat meningkatkan pengetahuan masyarakat Desa Sambeng Wetan sebagai salah satu langkah konkret untuk meningkatkan kualitas hidup masyarakat dan mengendalikan resistensi bakteri terhadap antibiotik.

\section{KESIMPULAN}

Berdasarkan hasil dari penelitian ini, dapat disimpulkan bahwa kegiatan edukasi tentang penggunaan antibiotik mampu meningkatkan pengetahuan kader kesehatan secara signifikan.

\section{UCAPAN TERIMA KASIH}

Terima kasih kepada Universitas Jenderal Soedirman yang telah membiayai dan memberikan fasilitas serta Desa Sambeng Wetan yang telah bekerjasama.

\section{DAFTAR PUSTAKA}

Healthcare, O. (2001). Antibiotic Resistance: Emerging Risks and the Partnership Solution. Ontario: Ontario Healthcare.

Jumiyati, F. N., Nugrahaeni, S. A., \& Margawati, A. (2014). Pengaruh modul terhadap peningkatan pengetahuan, sikap dan praktek kader dalam upaya pemberian ASI eksklusif. Journal of The Indonesian Nutrition Association Vol. 37 No. 1.
KEMENKES RI. (2011). Peraturan Menteri Kesehatan Republik Indonesia Nomor 2406/MENKES/PER/XII/2011. Jakarta: Kementerian Kesehatan RI.

Leekha, S., Terrel, C. L., \& Edson, R. S. (2011). General Principles of Antimicrobial Therapy. Symposium on Antimicrobial Therapy Vol. 86(2) (pp. 156-157). Maryland: Mayo Clinic.

Mardiastuti, H., Kurniawati, A., Kiranasari, A., Ikaningsih, \& Kadarsih, R. (2007, Maret ). Emerging Resistance Pathogen: Situasi Terkini di Asia, Eropa, Amerika Serikat, TImur Tengah dan Indonesia. Majalah Kedokteran Indonesia Vol 57 No. 3, pp. 75-79.

Maretha H., F. (2012). Tanggapan kader terhadap kunjungan masyarakat di posyandu serta faktor-faktor yang berhubungan di Puskesmas Jatimulya Kecamatan Tambun Selatan Kabupaten Bekasi tahun 2011. In Skripsi. Jakarta: Universitas Indonesia.

Neal , M. J. (2006). At a Glance: Farmakologi Medis Edisi Kelima. Jakarta: Erlangga.

Notoatmodjo, S. (2005). Promosi Kesehatn Teori dan Aplikasi. Jakarta: Rineka Cipta.

Pechere, J. (2001). Patients' Interviews and Misuse of Antibiotics. Clinical Infectious Disease Vol. 33 No. 3, S170-173.

Potter, P. A., \& Perry, A. G. (2005). Buku Ajar Fundamental Keperawatan : Konsep, Proses, dan Praktik, Edisi 4, Volume 2, Alih Bahasa : Renata Komalasari,dkk. Jakarta: EGC.

Pratiwi, H., Nuryanti, Utami, V. V., Warsinah, \& Sholihat, N. K. (2016). Pengaruh Edukasi Terhadap Pengetahuan, Sikap, Dan Kemampuan Berkomunikasi Atas Informasi Obat. Kartika-Jurnal Ilmiah Farmasi, Vol 4 No.1, 10-15.

Slameto. (2005). Belajar dan Faktor-faktor Yang Mempengaruhi. Jakarta: Rineka Cipta. 
ad-Dawaa Jour.Pharm.Sci., Vol. 1, No. 1

WHO. (2014). Antimicrobial Resistance :

Global Report of Surveillance. Geneva:

WHO. (2015). World Report On Ageing And WHO.

Health. Geneva: WHO. 